\begin{tabular}{ll}
\hline \hline MINING AND METALLURGY INSTITUTE BOR & ISSN: 2334-8836 (Štampano izdanje) \\
UDK: 622 & ISSN: 2406-1395 (Online) \\
\hline \hline
\end{tabular}

\title{
ANALYTIC USE OF MACROECONOMIC AGGREGATES
}

\begin{abstract}
Economic science has developed the whole system of so called macroeconomic aggregates - the system of a certain global and synthetic indicators which express the basic contents, dynamics and structure as well as the results of economic activity in some state or social community. The aim of this paper is to analyze the possible use of macroeconomic aggregates in the industries such as mining and metallurgy which support economic and social development of the north region of Kosovo and Metohija. The aggregate results of social production are indicators of volume, production and value structure of social production. Some aggregates like the national product and national income are used for recognition the dynamics and basic tendencies of economic development and total changes in national economy. Their absolute dimensions give the information on strength of national community economy, the same as possibility of its economic development. Focus of research will be directed on macroeconomic aggregates which are the expression of the social reproduction result that are the gross domestic product, national product and national income. These aggregates, together with unemployment, inflation and balance of payments are in the center of attention of macroeconomic analysis. Macroeconomic aggregates represent the important analytic categories because they provide an overview of structural elements of social reproduction, showing the direction of economic trends.

Keywords: economy, macroeconomic aggregates, national product, gross national income
\end{abstract}

\section{INTRODUCTION}

In order to estimate the result of some enterprise work, its incomes and expenses are compared or their difference - profit or loss. If the enterprise has earned a profit then it can be argued that the result of its operations is more or less good, depending on the profit amount and depending on the other indicators of successful business. Microeconomics deals with the result of analysis of a single enterprise.

A large number of various products are produced in an economy in a year, different kinds of goods are traded and the most various services are given, so a question can be asked how to determine a prosperity of the results which is achieved by a whole eco nomic system in a certain year. To include values and quantity of all those results of economic science production, macroeconomics as its part has developed the whole system of so called macroeconomic aggregates - the system of a certain global and synthetic indicator which expresses the basic contents, dynamics and structure as well as the results of economic activity in some state or social community.

Aggregate results of social production are indicators of volume, production and value structure of social production. They can be recognized from the standpoint of sector structure according to which it is known what is the contribution of achieved

\footnotetext{
*College of Economics Pec in Leposavic,24.Novembra, e-mail: savic22@yahoo.com
} 
results in operating of the primary, secondary, third and other economy sectors, what is a contribution of agriculture, industry, mining and others. If the certain economic aggregates are presented per capita or if they are calculated according to the structure of intended distribution of domestic product or national income, they can precisely express the level of economic development, as well as the level of living standard, and socioeconomic prosperity of people.

Some of presently used macroeconomic aggregates were already mentioned in the XVII century. Their more significant use in macroeconomic analysis started only in a period after the Great economic crisis. These aggregates, together with unemployment, inflation and balance of payment are in the center of attention of macroeconomic analysis. Macroeconomic aggregates represent the important analytic categories, because they provide an overview of structural elements of social reproduction, showing the direction of economic trends.

Considering the above mentioned, this paper has been systematized in three chapters. The first chapter of paper places the emphasis on the most comprehensive indicator, gross domestic product, factors which determine it considering its structure. The next chapter is focused on the national product and national income as two more accurate indicators of economy development as well as the certain social community. In the end, it is stressed where the macroeconomic aggregates can be met and due to that it is realized that they have a great significance for socio-economic planning, economic policy of a modern state and international comparison of national economies.

\section{GROSS DOMESTIC PRODUCT}

For the needs of its analysis, the macroeconomics has developed a great number of macroeconomic aggregates, and each of them, depending on the way of calculating and its structure, represents an indicator of the result or structure of the result of eco- nomic system. Nevertheless, the most used macroeconomic aggregate, either in economic analysis of concrete economy or in its comparison with the other economies is a gross domestic product and it is the most comprehensive indicator of the social production result of a certain national community.

Gross domestic product is the expression of total amount of produced goods and services which are produced in a certain national community during a year. To understand completely the essence of gross domestic product, it is necessary to have in mind: gross domestic product presents market value of all products and services produced in one state in a period of a year, which means that the market prices of goods and services are used for its calculation; the value of so called interphase products gets in calculating of this aggregate because its value has been calculated in the value of final production products (e.g. jewellery production is associated with the primary production of gold and silver, and its processing, wholesale and retail); gross domestic product includes only the products which are produced during an accounting year; calculation the gross domestic product includes only goods and services which are legally sold during a year meaning that this macroeconomic aggregate does not calculate the transactions on the black market; gross domestic product of domestic state including the goods and services, produced on its territory by the foreign companies or foreign citizens [1].

It is, also, necessary to stress the fact that the gross domestic product is macroeconomic aggregate which at the same time expresses two sizes - total income of economic subjects and total costs of all goods and services in a certain economy. It means that total income is always equal to total cost. The essence of this equality is in that if, let's say, one citizen of Serbia pays for the repair of electrical installation, that transaction is an expense for him. For the electrician who has done the repair work that transaction is an income. On that way, total income and 
total expense are really equal within one economy.

If one wants to understand what determines demand for goods and services, it is necessary to split the gross domestic product on integral parts, considering that there are different buyers of those goods. In the context of such analysis, the gross domestic product consists of: consumption (C), investment (I), government purchasing - state consumption $(\mathrm{G})$, export net $(\mathrm{NX})$ and investment in reserve (IZ) [2].

In the following lines, the above mentioned integral parts will be briefly explained: consumption consists of goods and services bought by individual buyer, or household, except a housing space; investment consists of bought goods for future production while the economists under investing foresee production of permanent capital goods (it means that if one deposits 5000euros from aid fund into a bank or buy government bonds, according to the economists no investment has happened, only one shape of financial property has been replaced with the other); state consumption includes purchasing of goods like: roads, airports, army, police, health institution, pension funds, etc. Within state expenses transfer payments should be excluded (e.g. payments for unemployment insurance, payments for war veterans, payments for elderly and disabled, health and social insurance, etc.); net export or foreign trade balance represents difference between the export and import of goods and services; the reserves are included because there are interests in total production and total sales transaction of any national economy, and if it is not a case, there is a difference between the produced and sold goods in a year and as a matter of fact it is investment in reserve.

Factors which determine a volume of gross domestic product are: natural resources (the main condition of every production are natural resources. Natural resources include the state and everything that comes along. Production process is in the essence changing and adapting the nature to human needs. To use natural resources properly, the production means must be developed. This is particularly evident in the mining and metallurgical industry where technology and degree of capacity utilization play a key role. Natural resources are just potential factor which has influence on a volume of gross domestic product); development of production means (people may live poor in naturally rich surroundings if they have no proper means, knowledge and capability to use them by the proper way and transform them in natural resources. Natural resources is defined as the all accumulated material goods which are owned by one society and present the work products of the past and present generations); population (population is permanent resource of labor without which the production process cannot be imagined. Number and structure of population in one state influence the volume and structure of consumption. The volume of gross domestic product will be bigger if that community has larger number of productively active population); labor productivity (labor productivity expresses productive powers of labor to produce larger or smaller amount of material goods for certain period of time. If the productive powers of labor is larger, manufacturer who owns it will be able to produce larger amount of products for the same time or one product for shorter time comparing with another manufacturer. Increased labor productivity is achieved if the certain material goods are produced in less time or if within the same time a larger quantity of material goods is produced. Labor productivity can be calculated as follows [13]:

\section{Model 1 Labor Productivity}

$$
\operatorname{Pr}=\frac{Q}{T}
$$

$\mathrm{Q}$ - production volume, $\mathrm{T}$ - time,

$\mathrm{Pr}$ - labor productivity.

The most important factors of productivity can be defined as: technical production 
process, organizational, personal factor of labor, socio institutional; intensity of labor (represents a degree of wear of human labor per time unit) [14]; social relations (social relations have important influence on the way and degree of use of all available human and material factors of production. If social relations are better, the manufacturer will have higher economic interest to enlarge the production volume [3].

The structure of gross domestic product can be considered from: natural and valuable (financial) aspect. When the gross domestic product is considered from the natural aspect then it presents a large number of qualitative different products and services. The gross domestic product considered from the natural aspect can be divided on products which are foreseen for production consumption, i.e. remanufacturing, and products that are intended for the final consumption. But, calculating the gross domestic product considered naturally would represent very complicated arithmetical operation, either due to a fact that different products are expressed in different measurement units (kilograms, centimeters, liters), or due to the fact that gathering of their data would be too big work .

Due to this, the goods considered in calculation of gross domestic product are calculated by their market prices which express what all goods and services have in common, and that is that they have a certain value. Expressing the gross domestic product by value, i.e. price indicators, is incomparable easier, considering that its total value is obtained multiplying the achieved production volume and provided services of all kinds multiplied with certain prices and then respective multiplicands are added. However, calculation of goods and services by their market prices brings another problem problem of unstable prices. Market prices change under different factors: variable relation of supply and demand, variable value of goods and services but variable money value (inflation, deflation, devaluation, revaluation).

\section{Material (natural) structure of gross domestic product}

Products of human labor satisfy different social needs. Some serve to the production consumption, i.e. they are used in production the new material goods, and the others are for personal consumption. Due to this, from this aspect, it can be said that natural structure of gross domestic product consists of all produced means for production (means for work and work objects) and consumption means.[4] Production means serve for satisfying the needs of production consumption while consumption means (disposable goods) are used for satisfying the needs of non-production or real consumption. Natural structure of gross natural product is presented with the model [11]:

\section{Model 2 Natural Structure of Gross Domestic Product}

$$
\mathrm{DBP}=\mathrm{SPR}+\mathrm{SP}
$$

DBP denotes the gross domestic product, SPR stands for means for production and SP denotes means for consumption. This division itself is conditional, because there is no sharp distinction between these two kinds of material goods, considering that many products can be used either in productive or nonproductive consumption.

\section{Value structure of gross domestic product}

Considering that domestic product is the result of one social community work during a certain period of time, the results in that the labor appears as the creator and common denominator of social product. Considering a man taking a part in production process, with his production experience and working habits, and production means, the live or current labor is differ 
entiated which invest a man in the production process, and the past labor which is contained in the production means. Live or current labor creates so called a newly created value which is added in the production process and as such increases the national wealth, and a transferred value is formed is formed within consumption.

Due to the heterogeneous parts of natural structure of gross domestic product, it is difficult to quantify it and collectively express. This is all because there is no appropriate measurement unit for settling the different goods on unique common quantitative indicator. Problem is solved examining a common content of all different use values which make the spent labor, which results in an idea of value structure presented by the following model [11]:

\section{Model 3 Value Structure of Gross \\ Domestic Product}

$$
\mathrm{DBP}=\mathrm{PB}+\mathrm{NB}
$$

Considering this, I t can be concluded that total value of gross domestic product (GDP) is equal to the addition of transmitted value (PV) and new created value (NV). It is necessary to stress that transmitted value consists of two elements: material costs of production and amortization [5]. A newly created value is a part of the value of gross domestic product, which size is determined by the quantity of spent newly added labor.

\section{Prosperity and factors which are not foreseen in BDP calculation}

Gross domestic product is not an incontestable indicator of economic and social prosperity of the people of a certain community. Prosperity of a society understood as a level of living trend (personal consumption and social standard), like the average consumption level (like products for food, clothes, shoes, living conditions and similar), measured by responsible amount of goods which include certain needs of collective consumption (education, health care, culture and similar) in an important part depend on gross domestic production level. That amount of goods and services which objectively enables a certain level of BDP do not have to mean to coincide with the level of economic prosperity of people and due to this reason that is difficult to imagine a possibility of equal distribution of that economical welfare to the individuals. According that, it is necessary to remember that BDP do not contain answer on a question who gets the products and uses the services which he is made of. Classical relations and especially relations in BDP distribution as well as politics of economic development and economical politics of national community in a certain period of time can significantly differ among states in spite of equality of their BDP per capita. Those are the reasons why the level of economical welfare of people and distribution of economical welfare among individuals differ in conditions of equality BDP of two national communities.

It is necessary to have in mind that needs structure of people of a certain national community, differentiated on a class basis, brings about also the production structure of BDP, which also influence the economic prosperity of people. Considering that calculation of BDP does not contain relations in distribution among individuals, so it cannot express their level of prosperity.

Socio-economic welfare of people of certain national communities can be different from a few factors which influence the life quality of individuals of national community and which are not calculated within the gross domestic product. The factors will be listed and explained briefly: there are products and services which do not appear on the market, fast scientific - technological changes which do not cause appearance of the product which are used for the same use (cars, computer, etc.) and which are of better quality than previously produced, and improving the quality is important for the level of economic prosperity and cannot express BDP considering that BDP is quantitative but not qualitative indicator and the whole row of other factors , which are not foreseen by BDP [6]. 


\section{NATIONAL PRODUCT AND NATIONAL INCOME}

The above mentioned shortage of gross domestic product caused the need to consolidate the indicator which will state the size of value of final goods and services of national community realized in a stated time (a year). That indicator is named a national product. National product includes all final goods and services which are not used as objects of labor in the next phase of labor process and business. As the financial indicator of production results, it is contained in depreciation (AM) as the financial expression of consumed means of labor and new realized value or national income (ND), produced in a certain period, which will be presented in a following way [6]:

\section{Model 4 National Product}

$$
\mathrm{DP}=\mathrm{Am}+\mathrm{ND}
$$

In other words, that is an indicator of financial amount of market realization the products and services which volume differentiate of the gross domestic product for the amount of transferred value on behalf of spent labor objects (interphase of consumption). This leads to the conclusion that domestic product appears as a positive difference between the gross domestic product (GDP) and value of consumed labor objects (material costs), shown as [6]:

\section{Model 5. National Product}

$$
\mathrm{DP}=\mathrm{DBP}-\mathrm{MTr}
$$

National product is often called the gross additional value, because it contains what producers of final products and services add through their own activities by the production of those products and delivering those services.

It is a material base of all types of final consumption, personal consumption, state or public and investment consumption. In the conditions when domestic community has a business with foreign communities, the size of values of final products and services, which appear as the positive or negative difference between the value of export and import of goods and services, will be included.

In statistics of industrial developed countries, according to methodology of the UN, the national product appears in two its shapes: gross domestic product or gross additional value and gross national product or gross national income.

Gross domestic product presents the collective expression values of final goods and services produced in a year or a quarter of a year within the borders i.e. the territory of one country (Table 1 gives an overview of this aggregate movement in a given period of time as the same of movement projections). Gross domestic product is a value of final goods and services whose sale brings incomes to home residents, independently if production was realized in the country or out of its borders [7]. In the other words, the gross national product is the gross domestic product increased by incomes that national residents have gained from the economic activity or based on the ownership in foreign countries, and reduced for incomes which are paid to non-resident business entities. Difference between the gross national product and gross domestic product is called the net income from economical activities and ownership in foreign countries. According to the above mentioned about these two indicators, it can be said that they will be qualitative equal if domestic residents have no activities in foreign countries as well as if foreign businesses have no involvement in a given community. 
Table 1 BDP and growth rate for the period 2005-2014 as well as projection of growth rate of domestic financial institution for 2015 and 2016 [8].

\begin{tabular}{|l|c|c|}
\hline Year & GDP (billions USD) & GDP growth rate \\
\hline 2005 & 25.06 & +5.4 \\
\hline 2006 & 29.33 & +3.6 \\
\hline 2007 & 39.16 & +5.4 \\
\hline 2008 & 47.67 & +3.8 \\
\hline 2009 & 40.24 & -3.5 \\
\hline 2010 & 36.38 & +1.0 \\
\hline 2011 & 43.77 & +1.6 \\
\hline 2012 & 38.09 & -1.5 \\
\hline 2013 & 42.49 & +2.6 \\
\hline 2014 & 42.65 & -0.6 \\
\hline 2015 & $/$ & +1.8 \\
\hline 2016 & $/$ & $+2.0[9]$ \\
\hline
\end{tabular}

National product, as all other value expressed macroeconomic aggregates, is total amount of produced goods and services multiplied with the unit price of product or service, as it is known, it is impossible to use the natural indicators. Depending on the price, the calculation is used in differentiate: nominal and real national product.

Nominal national product presents the national product which is calculated according to the current prices, i.e. prices of products and services which were current at the moment of calculation (problem is that the prices can change even in a short period of time). The real national product is obtained if the influence of price changing is excluded from the nominal national product (it is calculated according to the stable prices).

National income is macroeconomic aggregate which expresses total quantity of newly created value in the area of material production produced by the national community in a given period of time (usually a year). Thus observed as the value expression, this indicator is presented as difference between the total size of national production value (GDP) and transferred value (PV) which is [6]:

\section{Model 6 National Income}

$$
\mathrm{ND}=\mathrm{DBP}-\mathrm{PB}
$$

It can be calculated as difference between national product (DP) and depreciation $(\mathrm{Am})$, that is if the amount of transferred value is subtracted from national product for spent labor means, as follows [12]:

\section{Model 7 National Income}

$$
\mathrm{DP}-\mathrm{Am}=\mathrm{ND}
$$

As a new created value created by current labor in economy during the observed period, the national income is maximum value that the country can spend without any fear that it can endanger its own survival. It is important to point out that the level of living trend of population depends on national income amount as well as the level and possibility of economical development of a certain social community. Absolute size 


\section{ANALYTIC USE OF AGGREGATE PRODUCTION EXPRESSION}

and growth rate of this macroeconomic aggregate is used as the indicator of economy development degree. It expresses a development degree by very special way that is the same as a possibility of further development if it is expressed like a value size compared with the number of population of a certain national community. The national income per capita is obtained by this way.

National income per capita shows which part of total gross national product of a country would belong to every individual if it is distributed equally. It shows the general level of living standard of average inhabitant in one country. It is connected with the other instruments which show the social, economical and other welfare of a country and its inhabitants.

It can be said that the national income is equal to total wages, profits and rents, i.e. the sum of values of primary incomes of all institutional sectors. Only national income can be used for satisfying the needs of inhabitants and investments, while the transferred value of production factors must be back in a function of production. That is the way to compensate what existed before it was consumed in the production of the new material goods [6].

The national income is divided into 5 components, and those are: salaries of employees, owner income, private lease incomes from rents, corporation profits and net participation. These five categories can be expressed in the approximate percentage figures. It will be seen that the salaries take $70 \%$, ownership income $9 \%$, rents 2 , profits of companies $12 \%$ and net participation $7 \%$. It is important to point out that this division was done according to the way of acquiring the income [10].
Considering that three different sizes were stressed for marking the volume of material production, their analytic use and usefulness will be shortly analyzed. All three sizes have its sense and place either in theoretical or quantitative analysis but it is controversial which one has priority and greater importance. A certain number of economists consider that importance belongs to the gross domestic product because it deals with a large number of observable facts. The gross domestic product represents really an irreplaceable size in all analysis directed at exploring the inter-sectoral linkages and changes occurring in the structure of material production especially in relations between its basic sections. Beside that, it shows total domestic turnover of product, total amount of goods which should be exchanged in the economy and in a given period of time. In its structure, there are two additional components which have influence on creation and movements of other two sizes.

Two characteristics of gross domestic product should not be forgotten. The first, one part of gross domestic product that is transferred value of consumed raw material is a product of the past period or previous year which is only repeated in a new product. Society cannot utilize it, considering it has already been consumed, so it cannot subsequently be used for different purposes in economy. The second, in the gross domestic product expression, there are multiple repetitions of values of labor means that pass through many successive stages of processing. If there are more phases, if labor division is more developed and if there is the jagged state of economy then the number of these repetitions is higher as well. In 
that way, the gross domestic product expresses not just the real changes in production volume but, at the same time, all changes in organizational structure of economy and in social labor division. Its size can be influenced significantly by different organizational reorganization of production, higher or smaller degree of integration between the production units, regardless if there were the real changes at the level of material production.

These two reasons show that the gross domestic product is not the most appropriate size for expressing the real production volume and the pace of its changes in time, regardless from what particularly great difficulty inflicts its expression in constant prices, its conversion from current to constant prices. The above mentioned difficulties are such that practically disable the use of gross domestic product in the economic microanalysis which explores a longer time period. This, of course, does not reduce the mentioned analytical characteristics, which among others have a role to present very complex conditions in which production is done.

There are no multiple calculations in the gross domestic product and income and due to that it is possible to calculate the real production volume and achieved level and the pace of economic development, more effectively. The ability of production expansion and the level of satisfying and developing different social needs depend on their size.

According to all of that, it should be borne in mind the difference between these two sizes. Category of national income has only the net investments, and they are not enough, especially in one dynamic economy to express all real possibilities of expanded reproduction, considering that in such economy the depreciation also serve with its big part, in capital expansion and acceleration of economical growth. While exploring influence of investment on economical growth, it is necessary to consider total investments, i.e. investments which include depreciation. The national product which, beside national income, contains the depreciation, gives that wider opportunity for connecting and establishing the effects of total investments on production growth. In that sense, it can be considered as wider and more appropriate size in examining the basic interdependence which characterizes the process of economic growth.

Having in mind the analytic use of aggregate production expression, it can be concluded that every mentioned indicator has its own place in expressing the economical results. Depending on the "depth" and requirements of analysis, their use is differrent.

\section{CONCLUSION}

As it was seen, the gross domestic product is presented in global and short characteristics, as well as its distribution and shortcoming is stressed expressing as the most comprehensive aggregate. Namely, due to this multiple calculation the values of spent labor subjects; the gross domestic product inadequately expresses the size of total production value. At present, no matter on all that is used in macroeconomic analysis; it scrutinizes economical trends and has a great importance for the theory and practice in planning the development of one country, i.e. its economy.

The above mentioned shortcoming has conditioned the need to establish another indicator, national product and it entails all goods and services which are not used in the next phase as labor subjects. It is necessary to remind that the national product of a certain national economy, regardless it expressed through gross domestic or gross national product; it differs from the gross social product, total value of social production by the way that it does not contain the material costs, which appear depending on a number of market transactions of reproductive connected commodity producers. It can 


\section{REFERENCES}

be concluded that the size of gross domestic product would not differ from national product but only in the case that economy is organized as one enterprise and, in that case, the size of values of all final products and services would determine the both indicators. Hence, it is not the case in market economy, these two economy aggregates differentiate very much.

For better overview the macroeconomic activity, the national income is very often used. It is very complex to determine this size. Depending on its size - dynamic of growth, i.e. whether it declines or grows, the economical progress of society and living standard of population can be followed. Its special significance reflects in the international comparison of national product height per capita among certain countries. At present, in every and especially in developed countries, there is a systematic system to follow national income trends and its integral parts and there are necessary actions to provide necessary level of national income growth from year to year. Thus, the national income represents the most important indicator of direction the economical development and providing conditions for increasing the satisfaction of individual and collective needs of society that is constantly increasing.

Although, it is here pointed out their large application, it should not be forgotten that these are the most global aggregates which, however, cannot be the basis for a more detailed economic analysis. Since there is a need for such analyzes, such demands cannot be met thanks to the system of social accounting or macroeconomic balances.
[1] www.link-university.com

[2] Jednak J., Basics of Economics, High School of Professional Studies - Belgrade, 2008, pp. 280-281 (in Serbian);

[3] Devetaković S., Jovanović-Gavrilović B., Rikalović G. (2006), National Economy, Centre for Publishing of Faculty of Economics, Belgrade, p. 117 (in Serbian);

[4] www.apeiron-uni.eu

[5] www.docstoc.com

[6] D. Dragišić, B. Ilić, B. Medojević, M. Pavlović, Basics of Economics, Centre for Publishing of Faculty of Economics, Belgrade, 2004, p. 89-100 (in Serbian);

[7] www.knowledge-banks.org

[8] http://www.imf.org/external/error.htm? URL=http://www.imf.org/external/pub s/ft/weo/2014/01/weodata/weorept.a

[9] www.mfin.gov.rs

[10] www.vps.ns.ac.rs

[11] Stojadinović D., Macroeconomic Analysis, Publisher, Faculty of Economics Pristina, Blace, 2003, p. 99-100 (in Serbian);

[12] Komazec S., Ristić Ž., Macroeconomy - Macroeonomic Theory and Macroeconomic Analysis, Publisher, Etno Stil, Belgrade, 2011, p. 52;

[13] www.ef.uns.ac.rs/Download/poslovnastatistika/2014-04-21-Poslovna statistika-II-a.pdf

[14] www.singipedia.singidunum.ac.rs 


\begin{tabular}{ll}
\hline \hline $\begin{array}{l}\text { INSTITUT ZA RUDARSTVO I METALURGIJU BOR } \\
\text { UDK: } 622\end{array}$ & $\begin{array}{l}\text { ISSN: 2334-8836 (Štampano izdanje) } \\
\text { ISSN: 2406-1395 (Online) }\end{array}$ \\
\hline \hline & \\
UDK: $330.101 .541(045)=163.41$ & DOI:10.5937/MMEB1501097S
\end{tabular}

Marko Savić* , Nikola Pavlović*, Miloš Milanović

\section{ANALITIČKA UPOTREBA MAKROEKONOMSKIH AGREGATA}

\section{Izvod}

Ekonomska nauka je razvila čitav sistem takozvanih makroekonomskih agregata - sistem određenih globalnih i sintetičkih pokazatelja kojima se izražavaju osnovni sadržaji, dinamika i struktura, kao i rezultati ekonomske aktivnosti u nekoj državi odnosno društvenoj zajednici. Cilj ovog rada je da sagleda mogućnosti upotrebe makroekonomskih agregata u privrednim granama kao što su rudarstvo i metalurgija koji predstavljaju oslonac privrednog i društvenog razvoja regije severnog dela Kosova $i$ Metohije. Agregati rezultata društvene proizvodnje su pokazatelji obima, proizvodne i vrednosne strukture društvene proizvodnje. Pojedini agregati kao što su društveni proizvod i nacionalni dohodak koriste se za sagledavanje dinamike i osnovnih tendencija privrednog razvoja i ukupnih promena $u$ nacionalnoj privredi. Njihove apsolutne veličine pružaju informacije o snazi privrede nacionalne zajednice kao i o mogućnostima njenog privrednog razvoja. Fokus istraživanja biće uperen na makroekonomske agregate koji su izraz rezultata društvene reprodukcije, a to su društveni bruto proizvod, društveni proizvod i nacionalni dohodak. Ovi agregati zajedno sa nezaposlenošću, inflacijom i platnim bilansom nalaze se u centru pažnje makroekonomske analize. Makroekonomski agregati predstavljaju važne analitičke kategorije, jer pružaju pregled strukturnih elemenata društvene reprodukcije, pokazujući pravac privrednih kretanja.

Ključne reči: privreda, makroekonomski agregati, društveni proizvod, nacionalni dohodak

\section{UVOD}

Da bi se izmerio rezultat poslovanja određenog preduzeća porede se njegovi prihodi i rashodi odnosno njihova razlika dobit ili gubitak. Ako je preduzeće ostvarilo dobit onda možemo tvrditi da je rezultat njegovog poslovanja manje ili više dobar, zavisno od visine dobiti i zavisno od ostalih pokazatelja uspešnosti poslovanja. Analizom rezultata pojedinačnog preduzeća bavi se mikroekonomija.

$\mathrm{U}$ jednoj privredi se $\mathrm{u}$ toku godine proizvede mnoštvo najrazličitijih proizvoda, trguje se različitim vrstama robe i pružaju se najraznovrsnije usluge, pa možemo postaviti pitanje kako odrediti uspešnost rezultata koji

u određenoj godini ostvaruje čitav ekonomski sistem. Da bi se vrednosno i količinski obuhvatili svi ti rezultati proizvodnje ekonomska nauka, odnosno makroekonomija kao njen deo, razvila je čitav sistem takozvanih makroekonomskih agregatasistem određenih globalnih i sintetičkih pokazatelja kojima se izražavaju osnovni sadržaji, dinamika i struktura, kao i rezultati ekonomske aktivnosti u nekoj državi odnosno društvenoj zajednici.

Agregati rezultata društvene proizvodnje su pokazatelji obima, proizvodne i vrednosne strukture društvene proizvodnje. Mogu se sagledavati sa stanovišta sektorske

\footnotetext{
*Visoka ekonomska škola strukovnih studija Peć u Leposaviću, 24. Novembra b.b., e-mail: savic22@yahoo.com
} 
strukture na osnovu koje se saznaje o tome koliki je doprinos ostvarenim rezultatima privređivanja primarnog, sekundarnog, tercijalnog i drugih sektora privrede, koliki je udeo poljuprivrede, industrije, rudarstva i drugih. Ukoliko se određeni privredni agregati predstavljaju po glavi stanovnika ili ukoliko se obračunavaju na osnovu strukture namenske raspodele društvenog proizvoda ili nacionalnog dohodka mogu precizno izraziti nivo ekonomske razvijenosti, kao i nivo životnog standarda, odnosno ekonomskog i društvenog blagostanja ljudi.

Neki se od danas korišćenih makroekonomskih agregata pominju još u XVII veku. Njihovo značajnije korišćenje u makroekonomskoj analizi započinje tek u periodu posle Velike ekonomske krize. Ovi agregati zajedno sa nezaposlenošću, inflacijom i platnim bilansom nalaze se u centru pažnje makroekonomske analize. Makroekonomski agregati predstavljaju važne analitičke kategorije, jer pružaju pregled strukturnih elemenata društvene reprodukcije, pokazujući pravac privrednih kretanja.

Polazeći od svega navedenog, ovaj rad je sistematizovan u tri poglavlja. Prvo poglavlje rada akcenat stavlja na najobuhvatniji pokazatelj, bruto društveni proizvod, faktore koji ga određuju uz osvrt na njegovu strukturu. U narednom poglavlju fokusirali smo se na društveni proizvod i nacionalni dohodak kao dva realnija pokazatelja razvijenosti privrede a samim tim i određene društvene zajednice. Na kraju smo istakli gde se sve možemo sresti sa makroekonomskim agregatima i samim tim videli da oni imaju ogroman značaj za društveno planiranje, ekonomsku politiku savremene države i međunarodna poređenja nacionalnih ekonomija.

\section{DRUŠTVENI BRUTO PROIZVOD}

Makroekonomija je za potrebe svoje analize razvila veliki broj makroekonomskih agregata, a svaki od njih, zavisno od načina izračunavanja i svoje strukture, predstavlja pokazatelj rezultata ili strukture rezultata ekonomskog sistema. Ipak, najkorišćeniji makroekonomski agregat, kako u ekonomskim analizama konkretne privrede, tako i u njenom poređenju sa drugim privredama je društveni bruto proizvod $\mathrm{i}$ on je najsveobuhvatniji pokazatelj rezultata društvene proizvodnje određene nacionalne zajednice.

Društveni bruto proizvod je izraz ukupne veličine proizvedenih dobara i usluga koje se proizvode u određenoj nacionalnoj zajednici $\mathrm{u}$ toku jedne godine. Kako bi se u potpunosti razumela suština bruto društvenog proizvoda potrebno je imati u vidu: da bruto društveni proizvod predstavlja tržišnu vrednost svih proizvoda i usluga proizvedenih $\mathrm{u}$ jednoj zemlji u periodu od godinu dana to znači da se za njegovo izračunavanje koriste tržišne cene dobara i usluga; u obračun ovog agregata ulazi vrednost takozvanih međufaznih proizvoda jer je njihova vrednost obračunata i u vrednosti finalnih proizvoda proizvodnje (npr. proizvodnja nakita, povezana sa primarnom proizvodnjom zlata i srebra, a zatim njegovom preradom, trgovinom na veliko i na malo); bruto društveni proizvod uključuje samo proizvode koji su proizvedeni u toku obračunske godine; u obračun bruto društvenog proizvoda ulaze samo dobra i usluge koje su legalno prodate u toku godine što znači da ovaj makroekonomski agregat ne obračunava transakcije koje su izvršene $u$ okviru sive ekonomije; u obračun bruto društvenog proizvoda domaće zemlje ulaze i roba i usluge koje su na teritoriji domaće zemlje proizvele strane kompanije odnosno strani građani [1].

Treba, takođe, istaći i činjenicu da je bruto društveni proizvod makroekonomski agregat koji istovremeno izražava dve veličine - ukupan dohodak privrednih subjekata i ukupne troškove svih roba i usluga $u$ određenoj privredi. To znači da je ukupan dohodak uvek jednak ukupnom trošku. Suština ove jednakosti je u tome što ako, recimo, jedan građanin Srbije plati popravku elektroinstalacije za njega će ta transakcija predstavljati trošak. Za električara koji je popravku izvršio ta transakcija će predstavljati dohodak. Na taj način su u okviru 
jedne privrede ukupan dohodak i ukupni troškovi zaista jednaki.

Ako želimo da razumemo šta određuje tražnju za dobrima i uslugama, neophodno je rastaviti bruto domaći proizvod na sastavne delove, pošto imamo različite kupce tih dobara. U kontekstu ovakve analize bruto društveni proizvod se sastoji od: potrošnje (C), investicija (I), vladinih kupovina - državna potrošnja (G), neto izvoza (NX) i investicija u zalihe (IZ) [2].

$\mathrm{U}$ daljem radu, kratko ćemo objasniti gore navedene sastavne delove: potrošnja se sastoji od roba i usluga kupljenih od strane pojedinca, odnosno domaćinstava, izuzev stambenog prostora; investicije se sastoje od kupljenih dobara za buduću proizvodnju, dok ekonomisti pod investiranjem podrazumevaju proizvodnju trajnih kapitalnih dobara (to znači da ako pet hiljada eura iz blagajne stavimo u banku ili kupimo državne obveznice, prema ekonomistima nikakva se investicija nije dogodila, zamenio se samo jedan sa drugim oblikom finansiske imovine); državna potrošnja uključuju kupovinu dobara kao što su: putevi, aerodromi, vojska, policija, zdravstvo, penzioni fondovi itd., i kod državnih rashoda treba isključiti transferna plaćanja (npr: plaćanja za osiguranja od nezaposlenosti, primanja ratnih boraca, primanja starih i iznemoglih, zdravstveno i socijalno osiguranje itd.); neto izvoz ili spoljnotrgovinski bilans predstavlja razliku između izvoza i uvoza dobara i usluga; zalihe smo uključili, jer nas zanima ukupna proizvodnja, odnosno ukupne kupoprodajne transakcije bilo koje nacionalne ekonomije, a ukoliko to nije slučaj dolazi do razlike između proizvedenih $i$ prodatih dobara $u$ tekućoj godini $\mathrm{i}$ to je ustvari investicija u zalihe.

Faktori koji određuju obim društvenog bruto proizvoda su: prirodno bogatstvo (uslov svake proizvodnje predstavlja prirodno bogatstvo. U prirodno bogatstvo spada zemlja i sve što se u njoj nalazi. Proces proizvodnje je u suštini menjanje i prilagođavanje prirode ljudskim potreba. Da bi se prirodna bogatstva mogla koristiti moraju da budu razvijena sredstva za proizvodnju. Ovo posebno dolazi do izražaja u rudarstvu i metalurgiji gde tehnologija i stepen iskorišćenosti kapaciteta igraju ključnu ulogu. Prirodna bogatstva su samo potencijalni faktor koji utiče na obim društvenog bruto proizvoda); razvijenost sredstava za proizvodnju (ljudi mogu da žive vrlo siromašno u prirodno bogatom podneblju ako nemaju odgovarajuća sredstva, znanja i sposobnosti da ih iskoriste na pravi način te tako pretvore u društveno bogatstvo. Društveno bogatstvo se definiše kao sva nagomilana materijalna dobra kojima raspolaže jedno društvno a proizvodi su rada prošlih i sadašnjih generacija); stanovništvo (stanovništvo je trajni izvor radne snage bez koga se ne može zamisliti proces proizvodnje. Broj i struktura stanovništva u jednoj zemlji utiču na obim i strukturu potrošnje. Obim društvnog bruto proizvoda biće veći ukoliko ta zajednica raspoleže većim brojem proizvodno aktivnog stanovništva); produktivnost rada (produktivnost rada izražava proizvodnu snagu rada da se za određeno vreme proizvodi veća ili manja količina materijalnih dobara. Ukoliko je proizvodna snaga rada veća, proizvođač koji je poseduje biće u stanju da za isto vreme proizvede veću količinu proizvoda ili jedan proizvod za kraće vreme u odnosu na drugog proizvođača. Veća produktivnost rada ostvaruje se ukoliko se određeno materijalno dobro proizvede za kraće vreme ili ukoliko se za isto vreme proizvede veća količina materijalnih dobara. Produktivnost rada se može izračunati kao [13]:

Obrazac 1. Produktivnost rada

$$
P_{r}=\frac{Q}{T}
$$

Q - obim proizvodnje, $\mathrm{T}$ - vreme,

Pr - pro-duktivnost rada.

Najvažniji faktori produktivnosti mogu se definisati kao: tehničko-tehnološki, orga- 
nizacioni, lični faktor radne snage, društveno institucionalni); intenzivnost rada (predstavlja stepen trošenja ljudske radne snage u jedinici vremena) [14]; društveni odnosi (društveni odnosi imaju značajan uticaj na način i stepen korišćenja svih raspoloživih ljudskih i materijalnih činilaca proizvodnje. Što su društveni odnosi povoljniji za proizvođače, proizvođači će imati veći ekonomski interes da povećaju obim proizvodnje) [3].

Struktura bruto društvenog proizvoda se može posmatrati sa: naturalnog i sa vrednosnog (finansijskog) aspekta. Kada se bruto društveni proizvod posmatra sa naturalnog aspekta onda on predstavlja skup velikog broja kvalitativno različitih proizvoda i usluga. Bruto društveni proizvod posmatran sa naturalnog aspekta može se podeliti na proizvode koji su namenjeni proizvodnoj potrošnji odnosno ponovnoj proizvodnji i proizvode koji su namenjeni finalnoj potrošnji. Međutim, izračunavanje bruto društvenog proizvoda izraženog naturalno predstavljalo bi veoma komplikovanu računsku operaciju, kako zbog toga što se različiti proizvodi izražavaju u različitim jedinicama mere (kilogrami, centimetri, litri), tako i zbog toga što bi prikupljanje podataka o njima predstavljalo preobiman posao.

Zbog toga se dobra koja ulaze u obračun bruto društvenog proizvoda obračunavaju preko njihovih tržišnih cena koje izražavaju ono što je svim dobrima i uslugama zajedničko, a to je da imaju određenu vrednost. Izražavanje društvenog bruto proizvoda vrednosnim odnosno cenovnim pokazateljima je neuporedivo lakše, pošto se njegova ukupna vrednost dobija tako što se ostvareni obim proizvodnje i usluga svake vrste pomnoži najpre odgovarajućim cenama a potom pojedinačni umnošci saberu. Obračunavanje dobara i usluga po njihovim tržišnim cenama, međutim, nosi sa sobom drugi problem - problem promenljivosti cena. Tržišne cene se menjaju pod dejstvom različitih faktora: promene odnosa ponude i tražnje, promena same vrednosti dobara i usluga, ali i promena vrednosti novca (inflacija, deflacija, devalvacija, revalvacija).

\section{Materijalna (naturalna) struktura društvenog bruto proizvoda}

Proizvodi ljudskog rada zadovoljavaju različite društvene potrebe. Jedni služe proizvodnoj potrošnji, tj. koriste se u proizvodnji novih materijalnih dobara, a drugi su namenjeni ličnoj potrošnji. Zbog toga, sa ovog stanovišta, možemo reći da naturalnu strukturu društvenog bruto proizvoda čine sva proizvedena sredstva za proizvodnju (sredstva za rad i predmeti rada) i sredstva za potrošnju [4]. Sredstva za proizvodnju služe za zadovoljavanje potrebe proizvodne potrošnje dok se sredstava za potrošnju (potrošna dobra) koriste za podmirivanje potreba neproizvodne ili prave potrošnje. Naturalna struktura društvenog bruto proizvoda se predstavlja sledećim obrazcem [11]:

\section{Obrazac 2. Naturalna struktura}

društvenog bruto proizvoda

$$
\mathrm{DBP}=\mathrm{SPR}+\mathrm{SP}
$$

DBP označava društveni bruto proizvod, SPR označava sredstva za proizvodnju, a SP sredstva za potrošnju. Sama ova podela je uslovne prirode, jer ne postoji oštra granica između ove dve vrste materijalnih dobara, pošto se mnogi proizvodi mogu koristiti i u proizvodnoj i u neproizvodnoj potrošnji.

\section{Vrednosna struktura društvenog bruto proizvoda}

Pošto je društveni proizvod rezultat rada jedne društvene zajednice $u$ toku određenog vremena to se rad javlja kao tvorac i zajednički imenitelj društvenog proizvoda. Budući da u procesu proizvodnje učestvuje i čovek, sa svojim proizvodnim iskustvom i radnim navikama, i sredstva za proizvodnju, razlikujemo živi ili tekući rad, koji ulaže čovek $\mathrm{u}$ toku datog procesa proizvodnje, $\mathrm{i}$ 
preneti, minuli rad koji je sadržan u sredstvima za proizvodnju. Živi ili tekući rad stvara tzv. novostvorenu vrednost koja se dodaje u procesu proizvodnje i tako uvećava društveno bogatstvo, a utroškom minulog ili prenetog rada formira se preneta vrednost.

Zbog heterogenosti delova naturalne strukture društvenog bruto proizvoda teško ga je količinski zbirno izraziti. Sve ovo zbog toga što ne postoji prikladna jedinica mere za svođenje različitih dobara na jedinstven količinski zajednički pokazatelj. Problem se rešava posmatranjem zajedničkog sadržaja svih različitih upotrebnih vrednosti koji čine utrošen rad, čime se dolazi do pojma vrednosne strukture, koju možemo predstaviti sledećim obrascem:[11]

\section{Obrazac 3. Vrednosna struktura \\ društvenog bruto proizvoda}

$$
\mathrm{DBP}=\mathrm{PV}+\mathrm{NV}
$$

Iz ovog zaključujemo da je ukupna vrednost društvenog bruto proizvoda (DBP) jednaka zbiru prenete vrednosti (PV) i novostvorene vrednosti (NV). Potrebno je naglasiti da prenetu vrednost čine dva elementa: materijalni troškovi proizvodnje i amortizacija [5]. Novostvorena vrednost je onaj deo vrednosti društvenog bruto proizvoda, čija je veličina određena količinom utrošenog novododatog rada.

\section{Blagostanje i faktori koji se ne obuhvataju u obračunu BDP}

Bruto društveni proizvod nije pouzdan pokazatelj ekonomskog i društvenog blagostanja ljudi određene nacionalne zajednice. Blagostanje društva shvaćeno kao nivo životnog standarda (lične potrošnje i društvenog standarda), kao prosečan nivo potrošnje (kao što su proizvodi za ishranu, odevanje, oduvanje, stambeni uslovi i sl. ) mereno odgovarajućom korpom dobara koje uključuje i određene potrebe kolektivne potrošnje (obrazovanje, zdravstvo, kultura i sl. ) u značajnoj meri zavise od nivoa bruto društvenog proizvoda. Ta korpa dobara i usluga koju objektivno omogućuje određeni nivo BDP ne mora da znači da se podudara sa nivoom ekonomskog blagostanja ljudi i to iz prostog razloga što je teško zamisliti mogućnost ravnopravne raspodele tog ekonomskog blagostanja na pojedince. Pri tome treba imati u vidu da BDP ne sadrži odgovor na pitanje ko prisvaja proizvode $\mathrm{i}$ koristi usluge koje ga sačinjavaju. Klasni odnosi i posebno odnosi u raspodeli BDP, kao i politika privrednog razvoja i ekonomska politika nacionalne zajednice u određenom vremenu mogu se značajno razlikovati između zemalja i pored jednakosti njihovog BDP per capita. To su i razlozi što se po pravilu razlikuje nivo ekonomskog blagostanja ljudi odnosno raspodela ekonomskog blagostanja između pojedinaca $u$ uslovima jednakosti BDP - a dve nacionalne zajednice.

Potrebno je imati u vidu da stuktura potreba ljudi određene nacionalne zajednice, klasno izdiferencirane, uslovljava i strukturu proizvodnje BDP - a, što itekako utiče na ekonomsko blagostanje ljudi. Pošto obračun BDP - a ne sadrži odnose u raspodeli između pojedinaca, to on ne može da izrazi ni njihov nivo blagostanja.

Ekonomsko i društveno blagostanje ljudi određenih nacionalnih zajednica može biti različito iz čitavog niza faktora koji itekako utiču na kvalitet života pojedinca nacionalne zajednice, a koji se ne obračunavaju u okvirima bruto domaćeg proizvoda.

Nabrojaćemo faktore i ukratko objasniti: tu spadaju proizvodi i usluge koje se ne pojavljuju na tržištu, brze naučno - tehnološke promene koje uslovljavaju pojavu proizvoda koji služe istoj upotrebi (automobil, kompjuter i dr.) koji su kvalitetniji od primeraka predhodno proizvedenih, a to poboljšanje kvaliteta od značaja za nivo ekonomskog blagostanja ne može da izrazi BDP iz razloga što je on količinski, a ne kvalitativni pokazatelj i čitav niz drugih faktora koji nisu obuhvaćeni BDP - om [6]. 


\section{DRUŠTVENI PROIZVOD I NACIONALNI DOHODAK}

Navedeni nedostatak društvenog bruto proizvoda uslovio je potrebu da se utvrdi pokazatelj kojim će se iskazati veličina vrednosti finalnih dobara i usluga nacionalne zajednice ostvarenih $\mathrm{u}$ određenom vremenu (godinu dana). Taj pokazatelj naziva se društveni proizvod. Društvenim proizvodom se obuhvataju sva finalna dobra i usluge koji se ne koriste kao predmeti rada u naredenoj fazi procesa rada i poslovanja. Kao vrednosni pokazatelj rezultata proizvodnje sadrži se iz amortizacije (Am) kao vrednosnog izraza utrošenih sredstava rada i novostvorene vrednosti ili nacionalnog dohotka (ND) koja se proizvodi u određenom periodu, što ćemo prikazati na sledeći način [6]:

Obrazac 4. Društveni proizvod

$$
\mathrm{DP}=\mathrm{Am}+\mathrm{ND}
$$

Drugim rečima, to je pokazatelj veličine vrednosti tržišne realizacije proizvoda $\mathrm{i}$ usluga čiji se obim razlikuje od društvenog bruto proizvoda za iznos prenete vrednosti na ime utrošenih predmeta rada (međufazne potrošnje). Iz ovog zaključujemo da se društveni proizvod pojavljuje kao pozitivna razlika između društvenog bruto proizvoda (DBP) i vrednosti utrošenih predmeta rada (materijalni troškovi), i ovo prikazujemo [6]:

\section{Obrazac 5. Društveni proizvod}

$$
\mathrm{DP}=\mathrm{DBP}-\mathrm{MTr}
$$

Društveni proizvod često i nazivamo bruto dodatna vrednost, jer sadrži ono što proizvođači finalnih proizvoda i usluga dodaju svojom aktivnošću baveći se proizvodnjom tih proizvoda i vršenjem tih usluga.
On je materijalna osnova svih oblika finalne potrošnje, lične potrošnje, državne ili javne i investicione potrošnje. U uslovima poslovanja domaće zajednice sa inostranstvom obuhvatiće i veličinu vrednosti finalnih proizvoda i usluga koji se pojavljuju kao pozitivna ili negativna razlika između vrednosti izvoza i uvoza roba i usluga.

Društveni proizvod se u statistici industrijski visoko razvijenih zemalja, kao i po metodologiji UN pojavljuje u svoja dva oblika: bruto domaćeg proizvoda ili bruto dodatne vrednosti i bruto nacionalnog proizvoda ili bruto nacionalnog dohotka.

Bruto domaći proizvod predstavlja zbirni izraz vrednosti finalnih dobara i usluga proizvedenih u toku jedne godine ili jednog tromesečija u godini u granicama odnosno na teritoriji jedne zemlje (u tabeli 1 . dat je prikaz kretanja ovog agregata u određenom periodu, kao i projekcije kretanja). Bruto nacionalni proizvod je vrednost finalnih dobara i usluga čijom prodajom domaći rezidenti stiču dohotke nezavisno od toga da li je proizvodnja ostvarena unutar ili van granica sopstvene zemlje [7]. Drugačije rečeno bruto nacionalni proizvod je bruto domaći proizvod uvećan za dohotke koje su nacionalni rezidenti ostvarili od ekonomske aktivnosti ili po osnovu svojine u inostranstvu, a umanjen za dohotke koji se isplaćuju poslovnim jedinicama nerezidentima. Razlika između bruto nacinalnog proizvoda i bruto domaćeg proizvoda naziva se neto dohodak od ekonomskih aktivnosti i od svojine iz inostranstva. Na osnovu izloženog o ova dva pokazatelja možemo reći da će oni biti kvantitativno jednaki ukoliko domaći rezidenti nemaju nikakvih aktivnosti $u$ inostranstvu, odnosno ukoliko takođe strani poslovni subjekti nemaju nikakvog angažovanja u toj zajednici. 
Tabela 1. BDP i stopa rasta za period 2005-2014, kao i projekcija stope rasta domaće finansijske institucije za 2015. i 2016. [8]

\begin{tabular}{|c|c|c|}
\hline Godina & BDP (usd billions) & Stopa rasta BDP \\
\hline 2005 & 25.06 & +5.4 \\
\hline 2006 & 29.33 & +3.6 \\
\hline 2007 & 39.16 & +5.4 \\
\hline 2008 & 47.67 & +3.8 \\
\hline 2009 & 40.24 & -3.5 \\
\hline 2010 & 36.38 & +1.0 \\
\hline 2011 & 43.77 & +1.6 \\
\hline 2012 & 38.09 & -1.5 \\
\hline 2013 & 42.49 & +2.6 \\
\hline 2014 & 42.65 & -0.6 \\
\hline 2015 & $/$ & +1.8 \\
\hline 2016 & $/$ & $+2.0[9]$ \\
\hline
\end{tabular}

Društveni proizvod se, kao i svi ostali makroekonomski agregati izražava vrednosno, odnosno ukupna količina proizvedenih dobara i usluga se množi sa cenom po jedinici proizvoda ili usluge, jer je iz već poznatih razloga nemoguće koristiti naturalne pokazatelje. U zavisnosti od toga koje cene koristimo prolikom izračunavanja razlikujemo: nominalni i realni društveni proizvod.

Nominalni društveni proizvod predstavlja društveni proizvod koji je izračunat po tekućim cenama, odnosno cenama proizvoda i usluga koje su bile aktuelne u trenutku njegovog izračunavanja (problem je što se te cene mogu menjati i u kratkom vremenskom periodu). Realni društveni proizvod dobijamo ako iz nominalnog društvenog proizvoda isključimo uticaj kretanja cena (on se izračunava na osnovu stalnih cena). U ovom slučaju društveni proizvod, odnosno cena iz nekog baznog perioda.

Nacionalni dohodak je makroekonomski agregat koji izražava ukupnu veličinu novostvorene vrednosti u oblasti materijalne proizvodnje koju je proizvela nacionalna zajednica u određenom vremenu (obično se uzima godinu dana). Tako posmatran, kao vrednosni izraz ovaj pokazatelj se predstavlja kao razlika između ukupne veličine vrednosti društvene proizvodnje (DBP) i prenete vrednosti (PV) što izgleda [6]:

\section{Obrazac 6. Nacionalni dohodak}

$$
\mathrm{ND}=\mathrm{DBP}-\mathrm{PV}
$$

Može se dobiti i kao razlika između društvenog proizvoda (DP) i amortizacije (Am), odnosno ukoliko se od društvenog proizvoda oduzme iznos prenete vrednosti na ime utrošenih sredstava za rad, odnosno [12]:

\section{Obrazac 7. Nacionalni dohodak}

$$
\mathrm{DP}-\mathrm{Am}=\mathrm{ND}
$$

Kao novostvorena vrednost stvorena tekućim radom $\mathrm{u}$ privredi tokom posmatranog perioda, nacionalni dohodak je maksimalna vrednost koju konkretna zemlja može trošiti bez straha da može ugroziti vlastiti opstanak. Bitno je naglasiti da od veličine nacionalnog dohodka zavisi nivo životnog standarda stanovništva kao i nivo i mogućnost privrednog razvoja određene društvene zajednice. Apsolutna veličina i 


\section{ANALITIČKA UPOTREBA \\ AGREGATNIH IZRAZA PROIZVODNJE}

stopa rasta ovog makroekonomskog agregata koristi se kao pokazatelj stepena razvijenosti privrede. On posebno pregledno izražava stepen razvijenosti i mogućnost daljeg razvoja ukoliko se izražava kao vrednosna veličina stavljena $u$ odnosu sa brojem stanovnika određene nacionalne zajednice. Tako dolazimo do nacionalnog dohodka po glavi stanovnika ili nacionalnog dohodka per capita.

Nacionalni dohodak po glavi stanovnika pokazuje koji deo ukupnog bruto nacionalnog proizvoda zemlje bi pripadao svakom pojedincu ukoliko bi on bio ravnomerno raspoređen. On pokazuje opšti nivo životnog standarda prosečnog stanovnika jedne zemlje. On je povezan sa drugim instrumentima koji pokazuju društveno, ekonomsko i svako drugo blagostanje zemlje i njenog stanovništva.

Možemo reći da je nacionalni dohodak jednak ukupnim nadnicama, profitima i rentama, odnosno to je zbir vrednosti primarnih dohodaka svih institucionalnih sektora. Samo se nacionalni dohodak može upotrebiti za podmirenje potreba stanovništva i investicije, dok se prenesena vrednost faktora proizvodnje mora ponovo vratiti $\mathrm{u}$ funkciju proizvodnje. Time se nadoknađuje ono što je postojalo, a utrošeno je u stvaranju novih materijalnih dobara [6].

Nacionalni dohodak se deli na pet komponenti, a to su: zarade zaposlenima, vlasnički dohodak, privatni zakupni dohodak od rente, profiti korporacija i neto učešće. Ovih pet kategorija možemo iskazati i u aproksimiranim procentualnim iznosima. Videćemo da na zarade odlazi $70 \%$, na vlasnicki dohodak 9\%, na zakupnine od renti $2 \%$, profit firme $12 \%$ i na neto učešće $7 \%$. Bitno je napomenuti da je ova podela izvršena u zavisnosti od načina sticanja dohotka [10].
Pošto smo naveli tri različite veličine za obeležavanje obima materijalne proizvodnje, valja se kratko pozabaviti njihovom analitičkom upotrebom i svrsishodnošću. Sve tri veličine imaju svoj smisao i mesto kako u teorijskoj tako i kvantitativnoj analizi, mada je sporno kojoj od njih treba pridati prvenstveni i najveći značaj. Jedan broj ekonomista taj značaj pripisuje društvenom bruto proizvodu zbog širine tokova koje obuhvata. Društveni bruto proizvod predstavlja zaista nezamenljivu veličinu u svim analizama koje su upravljene na istraživanje međugranskih povezanosti i promena koje nastaju u strukturi materijalne proizvodnje, a posebno u odnosima između njenih osnovnih odeljaka. On, sem toga, pokazuje ukupan društveni obrt proizvoda, ukupnu veličinu dobara koju valja razmeniti u datoj privredi i datom vremenskom periodu. U svojoj strukturi sadrži takve dodatne komponente koje su od uticaja na formiranje i kretanje drugih dveju veličina.

$\mathrm{Ne}$ treba, međutim, izgubiti iz vida dve osobenosti društvenog bruto proizvoda. Prvo, jedan deo društvenog bruto proizvoda, tj. prenesena vrednost utrošenih sirovina, predstavlja proizvod prethodnog razdoblja ili prethodne godine koji se samo ponavlja u novom proizvodu. Njime društvo ne može raspolagati, budući da je već utrošen, te se ne može naknadno koristiti za različite svrhe u privredi. Drugo, u izrazu društvenog bruto proizvoda dolazi do višestrukog ponavljanja vrednosti predmeta rada koji prolaze kroz brojne uzastopne faze prerade. Ukoliko je broj tih faza veći, ukoliko je više razvijena podela rada i veća razuđenost privrede, utoliko je i broj ovih ponavljanja veći. Društveni bruto proizvod na taj način izražava ne samo stvarne promene u obimu proizvodnje, nego istovremeno i sve promene $\mathrm{u}$ organizacionoj strukturi privrede, $\mathrm{u}$ 
društvenoj podeli rada. Na njegovu veličinu mogu bitno uticati različita organizaciona preustrojstva proizvodnje, veći ili manji stepen integrisanosti proizvodnih jedinica, nezavisno od toga da li je došlo do stvarnih promena u nivou materijalne proizvodnje.

Iz oba navedena razloga društveni bruto proizvod nije najprikladnija veličina za izražavanje stvarnog obima proizvodnje i tempa njenih promena u vremenu, nezavisno od toga što naročito velike teškoće zadaje njegovo izražavanje u stalnim cenama, njegova konverzija sa tekućih na stalne cene. Navedene teškoće su takve prirode da praktično onemogućavaju upotrebu društvenog bruto proizvoda u ekonomskim makroanalizama koje se tiču dužih vremenskih razdoblja. Time se naravno ne umanjuju njegova ranije pomenuta analitička svojstva, koja se između ostalog sastoje u pružanju slike o veoma složenim uslovima u kojima se proizvodnja obavlja.

U društvenom proizvodu i nacionalnom dohotku nema ovog višestrukog obračunavanja i zato se pomoću njih adekvatnije može da izražava stvarni obim proizvodnje, dostignuti nivo i tempo privrednog razvoja. Od njihove veličine u krajnjoj liniji zavisi mogućnost proširivanja proizvodnje i stepen zadovoljavanja i razvijanja različitih društvenih potreba.

Treba pri svemu tome imati $\mathrm{u}$ vidu razliku između ove dve veličine. Kategorija nacionalnog dohotka sadrži samo neto investicije, a one nisu dovoljne, naročito $u$ jednoj dinamičnoj privredi, da izraze sve stvarne mogućnosti proširene reprodukcije, pošto u takvoj privredi i amortizacija znatnim svojim delom služi uvećanju kapitala i ubrzanju privrednog rasta. U posmatranju uticaja investicija na privredni rast nužno je uzimati u obzir ukupne investicije, dakle, investicije koje u sebi sadrže i amortizaciju. Društveni proizvod kojim je pored nacionalnog dohotka obuhvaćena i amortizacija, pruža tu širu mogućnost za povezivanje i utvrđivanje efekata ukupnih investicija na rast proizvodnje. $U$ tom smislu on se može smatrati širom i pogodnijom veličinom $u$ posmatranju osnovnih međuzavisnosti koje karakterišu procese privrednog rasta.

Imajući u vidu analitičku upotrebu agregatnih izraza proizvodnje, možemo zaključiti da svaki od navedenih indikatora ima svoje mesto $\mathrm{u}$ iskazivanju privrednih rezultata. Različita je njihova upotreba $u$ zavisnosti od ,širine" i potreba analize.

\section{ZAKLJUČAK}

Prikazani su, kao što smo videli u globalu i kraćim crtama društveni bruto proizvod, njegova raspodela $\mathrm{i}$ istakli smo njegove nedostatke koje ispoljava kao najsveobuhvatniji agregat. Uprabo zbog tog višestrukog obračunavanja vrednosti utrošenih predmeta rada društveni bruto proizvod neadekvatno iskazuje veličinu vrednosti ukupne proizvodnje. Danas se bez obzira na sve to on koristi u makroekonomskoj analizi, sagledava privredna kretanja i od velikog je značaja za teoriju i praksu planiranja razvoja jedne zemlje, odnosno njene privrede.

Navedeni nedostatak uslovio je potrebu da se utvrdi drugi pokazatelj, društveni proizvod i on obuhvata sva dobra u usluge koja se ne koriste $\mathrm{u}$ narednoj fazi kao predmeti rada. Potrebno je podsetiti da se društveni proizvod određene nacionalne privrede, bilo da se izražava preko bruto domaćeg ili bruto nacionalnog proizvoda razlikuje od društvenog bruto proizvoda, ukupne vrednosti društvene proizvodnje, utoliko što ne sadrži materijalne troškove, koji se pojavljuju zavisno od broja tržišnih transakcija reprodukciono povezanih robnih proizvođača. Možemo zaključiti da se veličina društvenog bruto proizvoda ne bi razlikovala od društvenog proizvoda samo ukoliko bi se privreda organizovala kao jedno preduzeće jer bi u tom slučaju veličina vrednosti svih finalnih proizvoda i usluga određivala oba pokazatelja. Pošto to u tržišnoj privredi nije slučaj, to se bitno razlikuju ova dva privredna agregata. 


\section{LITERATURA}

Radi boljeg sagledavanja makroekonomskih aktivnosti, često je u upotrebi nacionalni dohodak. Složeno je utvrđivanje ove veličine. U zavisnosti od njegove veličine odnosno dinamike rasta $t j$. da li on opada ili raste može se pratiti ekonomski napredak društva i životni standard stanovništva. Njegov poseban značaj se ogleda u međunarodnom poređenju visine nacinalnog proizvoda po glavi stanovnika između pojedinih zemalja. Danas se u svim, a posebno razvijenim zemljama sistematski prati kretanje nacionalnog dohotka i njegovih sastavnih delova i preduzimaju se potrebne mere da bi se obezbedio potreban nivo rasta nacionalnog dohotka iz godine u godinu. Tako nacinalni dohodak predstavlja najvažniji pokazatelj usmerenosti ekonomskog razvoja i obezbeđenje uslova za sve veće zadovoljenje pojedinačnih i zajedničkih potreba društva koje se stalno uvećava.

Iako smo istakli ovde njihovu veliku primenu, ne treba zaboraviti da je reč o najglobalnijim agregatima koji ipak ne mogu biti osnova za neku podrobniju ekonomsku analizu. Pošto često imamo potrebu za takvim analizama, takve zahteve možemo zadovoljiti zakvaljujući sistemu društvenog računovodstva ili makroekonomskih bilansa.
[1] www.link-university.com

[2] Jednak J. „Osnovi Ekonomije“ Visoka škola strukovnih studija - Beograd, 2008, str. 280-281.

[3] Devetaković S., Jovanović-Gavrilović B., Rikalović G. (2006) "Nacionalna ekonomija", Centar za izdavačku delatnost Ekonomskog fakulteta, Beograd, str. 117.

[4] www.apeiron-uni.eu

[5] www.docstoc.com

[6] D. Dragišić, B. Ilić, B. Medojević, M. Pavlović, Osnovi ekonomije, Centar za izdavačku delatnost Ekonomskog fakulteta u Beogradu, 2004, str. 89-100.

[7] www.knowledge-banks.org

[8] http://www.imf.org/external/error. $\mathrm{htm}$ ?URL=http://www.imf.org/ external/pubs/ft/weo/2014/01/weodata/ weorept.a

[9] www.mfin.gov.rs

[10] www.vps.ns.ac.rs

[11] Stojadinović D. "Makroekonomska analiza", izdavač, Ekonomski fakultet Priština, Blace, 2003, str. 99-100.

[12] Komazec S., Ristić Ž., ,Makroekonomija-makroekonomska teorija i makrekonomska analiza“ izdavač, EtnoStil, Beograd, 2011, str. 52.

[13] www.ef.uns.ac.rs/Download/poslovnastatistika/2014-04-21-Poslovna statistika-II-a.pdf

[14] www.singipedia.singidunum.ac.rs 